DEVELOPING AUTHENTIC E-LEARNING LISTENING MATERIALS OF NARRATIVE TEXT BASED ON LOCAL FOLKLORE FOR THE TENTH GRADE STUDENTS

AN ARTICLE

Submitted in Partial Fulfillment of the Requirements for the Degree of Sarjana Pendidikan

By

TITANIA AYU DWISARI

Registration Number. 2161121048

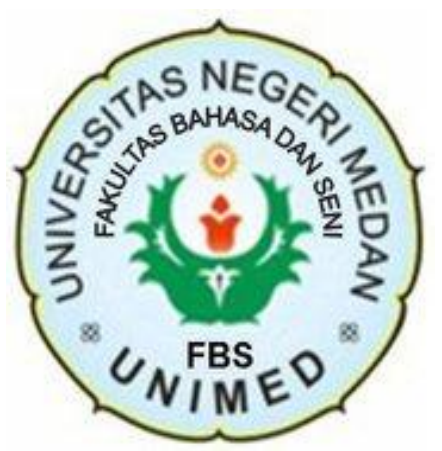

ENGLISH AND LITERATURE DEPARTMENT

FACULTY OF LANGUAGES AND ARTS

STATE UNIVERSITY OF MEDAN

2021 


\title{
DEVELOPING AUTHENTIC E-LEARNING LISTENING MATERIALS OF NARRATIVE TEXT BASED ON LOCAL FOLKLORE FOR THE TENTH GRADE STUDENTS
}

\author{
*Titania Ayu Dwisari \\ **Dr. Anni Holila Pulungan, S.Pd., M.Pd.
}

\begin{abstract}
Dwisari, Titania Ayu, 2161121048. Developing Authentic E-Learning Listening Materials of Narrative Text Based on Local Folklore for The Tenth Grade Students. A Thesis, English Educational Program, Faculty Language and Arts, State University of Medan, 2021.
\end{abstract}

The objective of this study was to develop authentic E-learning listening materials of narrative text based on local folklore for the tenth-grade students in SMA Plus Sedayu Nusantara. This study was conducted by using Research and Development design through six stages; gathering data and information, need analysis, materials development, validating by experts, revising, and final product. The subject of the study was the tenth-grade students in SMA Plus Sedayu Nusantara. The data were gathered by reviewing documents, conducting an interview with the English teacher, and distributing the students' needs analysis questionnaires to X MIA 4 consists of 27 students to get the students' needs. The interview and questionnaire results proved that the students needed authentic E-learning listening materials based on local folklore. The developed reading materials were validated by two experts which scored 3.52 and 4.79 on average. The scores approved that the authentic E-learning listening materials based on local folklore were valid and very valid to use for the tenth-grade students in SMA Plus Sedayu Nusantara. The result of the product was distributed to the students through Blog.

Key words: Development, E-learning, Listening Materials, Authentic Materials, Local Folklore, Blog.

\footnotetext{
*Graduate Status

***ecturer Status
} 


\section{INTRODUCTION}

\section{A. Background of the Study}

In the realm of learning language, there are four skills that the students necessitate to be proficiently advanced. One of the four language learning skills that perform an influential role is listening. Due to its prominent presence in language teaching and learning, the students have to be competent in mastering this skill as they also have to master the other language skills. Consequently, the teachers obliged to accommodate the learners with the proper materials in their teaching instruction during the process of teaching and learning listening.

During the process of teaching listening, the teachers struggle to teach the encountered obstacle, for instance, the provided listening materials. A study by Ekawati (2019) has pointed out the major problem experienced by the teachers in teaching listening concerns about how the materials presented. The listening materials discovered in the provided textbook do not potentially intensify the students' listening proficiency since the portion of the presented materials and activities given are fewer compared to the other skills. Additionally, the audio for listening materials do not fully outfit the learning process, it is either the audio is not available, or the additional audio formats do not function well, due to the failure of the technicality factor. Inevitably, those kinds of listening materials are exceptionally not authentic, as authentic materials refer to oral and written materials used in daily situations, for example, newspapers, magazines, television, radio, and the internet (Erbaggio, et al., 2012). Therefore, the listening materials are not authentic when the teacher recorded, pronounced, and presented the audio in the classroom as the recording may not provide the students with some valuable exposure to the 
actual used of language itself (Brown: 2001). Furthermore, not all the teachers are expert in narrating the listening narrations or becoming the storytellers.

As the students need to experience how the language works in the real situation, the existence of the students' local cultural element must be considered adequately during language teaching and learning. This narrative accountably established by Richards and Renandya (2010) that stating an effective teaching material is the one that presenting cultural and linguistic input and an excessive selection of integrated activities.

However, a study conducted by Seftika (2017) has mentioned that numerous young generations do not acknowledge and understand their cultural surroundings as well as their own culture. This statement accountably has confirmed by a study conducted for the tenth-grade students at SMA Plus Sedayu Nusantara that $64.7 \%$ were not familiar with the story of Hikayat Putri Hijau and $76.5 \%$ were not familiar with the story of Kolam Sampuraga. The reason why the students were not familiar with these local folklores from North Sumatra was that they never heard and knew that these stories existed and still belong to North Sumatra local folklore.

The advancement of technology has shifted our conventional way of doing and working on something in various fields, including the education world. It is also one of the factors that inspire teachers to be more creative in developing their teaching materials as the Indonesia education system still holds in belief to paper-based materials a lot. Thus, the existence of numerous digital platforms is crucial to support teachers in presenting their teaching material and assist the students in acquiring the materials efficiently. 
However, based on the observation data from the interview that has been conducted by the researcher with an English teacher at SMA Plus Sedayu Nusantara, it was discovered that; The content of the stories that were available in the textbook, mostly about fairy tales and folklores, but the provided folklores were not authentically presenting the local stories from North Sumatra. The supporting audios also had technical problems, and the teacher never operated them since the supplied audios did not equip with what was being learned.

Generating from the encountered problems, it seems necessary to take action by developing authentic E-learning listening material based on local folklore of narrative text for the tenth-grade students. This study is intended to be conducted to develop authentic E-learning listening material based on local folklore to teach narrative text for the tenth-grade students at SMA Plus Sedayu Nusantara. This authentic E-learning listening materials based on local folklore were developed based on the needs of the students.

\section{REVIEW OF LITERATURE}

\section{A. Theoritical Framework}

In supporting the theoretical concept in this research, some books containing information and theories are presented to assist the researcher. These theories are essential as they carried the fundamental grounds in analyzing this research.

\section{Listening}

Wallace (2004:13) states that listening skill is a highly important skill because this ability enables human to acquire perception, knowledge, information, and success in communicating with others. Concerning that 
citation, listening is a particularly crucial skill in learning English since it requires a human's recognition of perceiving communication between others. Consequently, listening is the capacity where humans make use of their experience of listening to concentrate and recognize what the speaker means. From the definition, it can be concluded that listening is a complex process of interpretation in which listeners can correspond to what they have heard with what they have already known by apprehending the messages, analyzing, evaluating, and giving feedback to what the speaker has said.

\section{Authentic E-learning Materials}

Herod (2002) states that authentic learning material and activities are designed to resemble real-world situations. Jacobson (2003) further defines authentic material as a printed material practiced in the classroom in an identical way as it would be used in real life.and can be classified into three categories of authentic materials; Authentic listening-viewing materials, Authentic visual materials, Authentic printed materials (Lingzu \& Yuanyan, 2010). Peacock (1997) additionally distinguishes this material as the materials produced to accomplish any social purposes in the language community. In conclusion, authentic materials are the materials that can expose the students to the real use of language. The teacher can obtain these materials through the various things that can be discovered around the class.

Clark (2016) defines that E-learning is as instruction presented on a digital device (such as computer, laptop, tablet, or smartphone) and meant to assist the process of teaching and learning. Garrison (2016) further describes Elearning as virtually mediated communication to construct and confirm the knowledge through the internet and correlated communication technologies. 
Therefore, E-learning platforms reckon as virtual learning environments, where teachers can utilize them as tools for designing and creating online courses for students through online websites for learning without the time and space restrictions of the conventional learning environment. Consequently, Authentic E-learning materials conclude as internet-based platforms that can incorporate virtually with authentic types of materials context to preserve the complexity of the real-life setting for teaching and learning listening.

\section{Materials Development}

Material development defines as a process of producing and utilizing the materials for language teaching and learning processes, including materials evaluation adaptation, design, production, exploitation, and research (Tomlinson, 2012:143). In correlation to this study of developing authentic Elearning listening materials to teach Narrative, several aspects have to be taken into accounts:

\section{a. Need Analysis}

Hutchinson and Waters (1987: 54) refer needs as the capability to perceive and to create linguistic features into two categories, namely learning needs, and target needs. Learning needs define as what knowledge and abilities will the learners need to be able to perform to the required degree of competence in the target situation. Meanwhile, the target needs deal with what learners need to do in the target situation. The analyses of the target are necessities, lacks, and wants. 


\section{b. Curriculum}

The recent curriculum implemented in school is curriculum 2013. It designates that education aims to improve three aspects of student's competences, which are attitude, knowledge, and skill. Those competencies designed to include the core competencies (KI), which have one or more basic competences (KD). The first and second core competencies (KI-1 and KI-2) implemented to increase the students' religious and social competences. The third and fourth core competencies (KI-3 and KI-4) applied to develop the students' knowledge and skill competencies. Moreover, curriculum 2013 constitutes a scientific approach as the guidance in the language teaching and learning process. The scientific approach used in the language classroom is as follow: i) Observing, ii) Questioning, iii) Collecting data or information, iv) Associating/ analyzing, and v) Communicating.

\section{c. Syllabus}

Based on The Ministry of Education and Culture Regulation No. 65/2013, the syllabus is a framework to design learning activities and materials for every subject. A syllabus comprises some aspects, at least; Mata pelajaran (subject), Identitas Sekolah (The name of the school), Kompetensi Inti (Core competence), Kompetensi Dasar (Basic Competence), Kegiatan Pembelajaran (Learning Activities), Penilaian (Assessment), Alokasi Waktu (Time Allocation), and Sumber Belajar (Learning sources). Despite causing the course becomes manageable; the syllabus points the objectives to the goal. The teacher can assess the students' progress in terms of what they have achieved. Through the syllabus, the students and the teacher can recognize what they will 
learn, but also why it is necessary to learn the topics. It proffers the learning process worthy and meaningful.

\section{d. Learning Materials}

The Ministry of Education and Culture Rule No. 81A year 2013 affirms the standards of the English learning materials based on curriculum 2013 are as follows:

a. The taught materials intended to develop language competency.

b. Students practiced themselves to be able to perceive, comprehend, and interpret the meaning of the text, summarize, and then present it with their language.

c. Students exercised themselves to produce text systematically, logically, and effectively.

d. The teachers teach the students how to create contextual text.

e. The teachers encourage the students to practice how to express themselves and their knowledge using the target language confidently and fluently.

In this research, the materials were equipped into an E-learning platform as the learning resource named Audioable. Audioable powered by Blog is a digital platform developed to serve the listening materials that correlate with local folklore narrative stories that can assist teachers to teach the narrative text in based on the need analysis of the tenth-grade students.

\section{Narrative Text}

Rebecca (2003) has written in Teaching English 4 All, describes a narrative text is a text used to narrates a series of coherent, and chronological events, caused or experienced by factors. The narrative text is the kind of text 
used to narrates a story, mainly used to entertain, motivate, or teach. It intends to get attention and maintain enthusiasm.

From the explanation above, Narrative text concludes as a story that used oral or written language, which narrates a series of coherent and chronological events, which function is to entertain the reader, or the listener, and also carries a moral value within the story.

\section{Local Folklore}

Hayati and Bakhtaruddin $(2016,414)$ state that folklore is the oral literature that has been handed down from generation to generation in the community of its owner.

According to Danandjaja (1994: 50-51) that Folklore is divided into three major classes, namely myths, legends and fairy tales or folktales. From the definitions above, it can be concluded that folklore is a type of oral literature usually told by parents or family members or community leaders to children, mostly during both in their free time and at bedtime. Folklore can be used as a strategic means to plant, foster, and develop various values that want to be passed on to children aimed at character building.

\section{RESEARCH METHODOLOGY}

This research was conducted by implying Educational Research and Development (R\&D). Borg and Gall (2003) state that Educational Research and Development based on the development model, by means, the findings of the research used to design brand new educational products and procedures, which systematically field-tested, evaluated, and refined until specified criteria of effectiveness, quality, or similar standards was accomplished. The research 
findings were used to develop new products and procedures. This research was conducted in SMA Plus Sedayu Nusantara located in J1. Marelan, Ps. III Timur. The Subject of this study was one class of grade tenth at SMA Plus Sedayu Nusantara. The class was X MIA 4, it consisted of 27 students.

In collecting the data, this research was conducted by observing and reviewing the documents such as the syllabus and textbook. Then interviewing the teacher to obtain information about the listening materials and media that teacher used in the classroom and the difficulty that teacher encountered during the process of teaching and learning, and distributing questionnaires to students to discover the students' needs to receive the data about the developing of authentic E-learning listening materials.

After gathering data, information also needs analysis, the researcher developed the listening materials, then validated to experts, revised, and the result of the revised product was the final product, these steps were adapted from Borg and Gall's research and development theory (2003), with some modifications which become six steps of R \& D cycle.

\section{DATA ANALYSIS, FINDINGS AND DISCUSSION}

\section{A. Research Result}

The authentic E-learning listening materials were developed by using several stages, those are;

1. Gathering data and information by using some instruments, namely: document, interview, and, questionnaire. based on the reviewing documents (syllabus, textbook), the basic competence in syllabus stated that the grade tenth students had to be able to gain the ability to comprehend the 
variety of ideas which had communicative purposes, text structure, and certain linguistics features, found in daily-life contexts dialogue, simple short functional, and monologue texts in the types of the narrative. Then, the researcher discovered that the content of the stories that were available in the textbook, mostly about fairy tales and folklore, but the provided folklores were not authentically presenting the local stories from North Sumatra.

After reviewing the documents, the researcher also acquired data from an interview with the tenth grade English teacher in SMA Plus Sedayu Nusantara. Based on the interview, the researcher found out that authentic Elearning listening materials based on local folklore had never been applied in SMA Plus Sedayu Nusantara as the materials in teaching the narrative text. Moreover, it was discovered that the teacher considered that the use of Elearning materials for listening are urgently required since the audio did not fully outfit the learning process due to the unavailability and the failure of the technicality factor. Furthermore, the current status quo demanded the process of teaching and learning emerged into E-learning. The result of the interview can be seen in Appendix B. The researcher perceived this situation as an opportunity to develop authentic E-learning listening materials based on local folklore.

2. Need analysis, it discovered that in target analysis, firstly, the students' goals were to able to contextually catch the meaning as well as distinguish the social functions, text structures, and language features of the spoken and written narrative texts concerning the legend stories based on its 
usage contexts. It was proven that $100 \%$ of the students in SMA Plus Sedayu Nusantara answered the question item with yes.

Secondly, the students' necessities, $100 \%$ agree to use E-learning and $70.4 \%$ authentic materials are necessary for them to learn listening narrative text. Consequently, authentic materials can be a fundamental determinant for students to learn effectively in the target situation.

Thirdly, the students' lack, $100 \%$ of students agreed that they had ever experienced difficulties in comprehending the listening scripts during the process of learning narrative text due to the inability of comprehending the coherence and chronology of the narrative text (70.9\%), passive attitude in the process of listening activity during the period of learning narrative text (100\%), and not applying authentic E-learning materials in learning listening for the topic of narrative text (96.3\%). Inevitably, It was necessary to apply authentic materials, as the students did not fully understand the narrative text, and authentic materials were approved to be useful in encouraging the students to understand the materials very well as it applied daily-life content in its application.

Forth, the students' want, it was revealed $100 \%$ of the students want to use authentic E-learning materials in learning listening for narrative text. Moreover, $100 \%$ of the students were needed to apply authentic E-learning materials in studying listening for narrative text. After acknowledging that the students need to apply authentic E-learning materials, the input was endeavored to discover whether the students want to use authentic E-learning as the materials, and all of them consented to it. 
3. Materials development, developing the authentic listening materials based on local folklore as the supplement of learning to accommodate the core competence, basic competence, indicator, learning objectives, and syllabus based on the 2013 curriculum and scientific approach (observing, questioning, collaborating, associating and communicating). The developed listening materials of the narrative text for the tenth-grade students in SMA Plus Sedayu Nusantara was obtained from the students' needs analysis. Those data were used as the guidance to develop the materials. Here are the descriptions of the steps:

\section{a. Brainstorming}

During this activity, the students' responses might be varied. Next, the teacher questions the students with another question about whether they knew any local folklore stories from North Sumatera. During this period, the students were expected to share any local folklore stories from North Sumatera they knew. Hence, the brainstorming aimed to introduce the students with the material before getting into the main activities.

\section{b. Main Activity}

The main activity was developed by using the scientific approach. Here are the descriptions of the steps:

\section{$>$ Observing}

In the observing cycle, the teacher provided the students with a video about a local folklore story from North Sumatra entitled Hikayat Putri Hijau that could be accessed in Video Menu . When the teacher displayed the video, the students were assigned to listen, watch and observe the video. Through this 
activity, the students were expected to have the sense of curiosity before proceeding to the activity in questioning cycle.

\section{Questioning}

After the students had completed the observing cycle, the next step was questioning. In questioning, the teacher encouraged the students to raise questions after they had watched and listened to the video displayed in observing cycle.

Meanwhile, if the worst scenario happened where there was no student raising any questions, consequently, the teacher tried to iniciate questions for the students to answer. The potential questions that could be asked by the teacher to the student were based on the story of Hikayat Putri Hijau, including the social function, the language features, and the generic structures of the text.

\section{Exploring}

The next cycle after questioning was exploring. In this cycle, the teacher formed the students into groups and re-explained about the tasks instructions as well as making sure that they had understood about what they would do, before assigning them to find out the specific details from the passage.

During this cycle, the teacher monitored each of the group to stay on their lane by providing guidance in case they had questions to ask or having difficulty in understanding the questions or doing the instructed tasks.

\section{$>$ Associating}

After exploring the text of Hikayat Putri Hijau and finding out the specific information in it, the students as groups were instructed to further analyze the text deeper by discovering the conflict, resolution, and moral of the story. Next, 
they compiled the result of their discussion and made sure that each of the group members understood what they had already discussed.

During this cycle, the teacher made sure that the discussion run smoothly and each member of the group already understood their work and the teacher also provided solution in case the students are in difficulty in doing the task.

\section{$>$ Communicating}

In the last cycle of the scientific approach named communicating, the students as groups are asked to be involved in the activity called 'Detour route'. In this activity, the groups will assign a representative to explore another group's result of discussion in associating cycle and compare it with their work as well as sharing their result with the other groups. After visiting every group and obtain the information from all the groups, the representative will go back to their group and share what they have to their member and fix their report. During this cycle, the teacher will make sure that the representatives have visited every group and maintain the time management.

\section{c. Post Activity}

In this activity, there are several activities included to be experienced by students

\section{$>$ Reflection}

In this activity, both in the first and second meetings, the students allow reflecting on how much they have learned in this meeting by answering the provided questions as the parameter to make sure their understanding. During this activity, the teacher also must be prepared to provide solution in case the 
students still get no clue about the materials they have learned during each meeting.

4. Experts' Validation, the first expert validation from the lecturer was 3.52 or 88 , and it was classified as "good or valid". The second expert by the English teacher was 4.75 or 95.2 , and it was classified as "very good or very valid" Hence, the authentic E-learning materials were valid and relevant to be applied in teaching listening narrative text for the tenth-grade students in SMA Plus Sedayu Nusantara.

5. Revision, the suggestions suggested by the lecturer were to make the learning objectives written in the lesson plan in line with what have written in the materials, to apply the proper and relevant taxonomy bloom's verbs in the learning outcomes that support the process of teaching listening, and also to add clear instructions. Meanwhile, the suggestions offered by the teacher was not to add any adjustments nor change towards the authentic E-learning materials, but the teacher expected that in the future, it is not only the listening materials for the narrative text that was developed but also any other genre of texts based on the syllabus.

6. Final product, after accomplishing all the materials revision based on the experts' suggestions, the authentic E-learning materials was finalized as a complete product. The authentic E-learning materials were developed based on the students' needs and had been perceived as valid to be used by experts. The complete final product can be accessed from https://itsaudioable.blogspot.com/ 


\section{B. Discussion}

After distributing the questionnaire and analyzing the existed listening materials to teach narrative text; the researcher discovered that the existing listening materials in SMA Plus Sedayu Nusantara did not comprise the local cultural element. Moreover, the audio or video to support the listening activity was unfit and fail to operate. These problems were in line with the study conducted by Ekawati (2019) that points out that the major problem experienced by the teachers in teaching listening concerns how the materials are presented. Meanwhile, Richards and Renandya (2010) proposed effective teaching material is one that presenting cultural and linguistic input. Futhermore, Tomlison (1988) adds materials should exhibit the learners to the authentic use of the language.

In developing listening materials for the narrative text, the researcher developed materials based on scientific approach stages. The materials were developed to support the two-time meeting. In developing the materials, firstly, the researcher developed indicators into the lesson plan by applying the scientific approach. Next, the materials developed related to the stages. For instance, in the observing, the researcher provided the students with a video about the story of Hikayat Putri Hijau to help them learn about the narrative text and practice their listening ability. Some worksheets were also developed to support the learning process such as finding out the specific information about the story. After completing the listening materials, the researcher converted the materials into E-learning as the materials were posted to the Blog to make the students and teacher easily access the materials. As Khan (2016) 
emphasizes that E-learning is a beneficial solution in the whole education set up to overcome the drawbacks discovered in traditional education.

In developing the materials, the researcher concentrated on the activities that could assist students in utilizing technology, the researcher developed activities that involved E-learning, it supported teachers to present the materials in this pandemic situation effectively, the use of technology in the activities also could interact students in learning listening because, in their needs, they wanted to use technology while learning process. Thus, it is in line with Alm (2013) explains that the application of E-learning for the out-of-class listening practice can encourage the students to develop a routine of sustained listening and to reflect on their learning.

\section{CONCLUSION AND SUGGESTIONS}

\section{A. Conclusion}

The researcher concludes that during the process of teaching and learning listening narrative text in SMA Plus Sedayu Nusantara, it was discovered that the existed materials did not channel the students' local cultural background, and there was no audio or specific listening materials existed. Moreover, all the materials on the students' textbooks were still paper-based. Consequently, the researcher developed authentic E-learning. After the materials have been developed, the materials were validated by two experts. The developed materials used the scientific approach (observing, questioning, exploring, associating, and communicating). The average scores were 3.52 or 95.2, which translated as valid and very valid. The final listening materials can be accessed on https://itsaudioable.blogspot.com/. 


\section{B. Suggestions}

After analyzing the data and developing the authentic E-learning listening materials based on local folklore. Here are some suggestions which are in alignment with the before mentioned conclusions:

1. It is suggested that the recently developed materials should be applied by the English teacher to encourage students in SMA Plus Sedayu Nusantara during the listening activities. As a result, it is expected to gain a significant improvement in the students' listening ability.

2. It is suggested teacher should be more responsive and aware of the students' need in learning listening for the narrative text, such as their needs in materials usage, learning sources, and learning kits.

3. Due to limited time, this research only develops the materials for two-times meeting for the students' listening purposes in learning narrative text. Therefore, it is expected to other researchers to develop other aspects of narrative text and listening, or other genres and skills in different grades that can be analyzed to solve the encountered problems found during the teaching and learning process.

\section{REFERENCES}

Alm, A. (2013). Extensive Listening 2.0 with Foreign Language podcasts. Innovation in Language Learning and Teaching, 7(3), 266-280.

Brown, G., Gillian, B., Brown, G. D., \& Yule, G. (1983). Teaching the Spoken Language (Vol. 2). Cambridge University Press.. Retrieved April 18, 2020, from https://archive.org/details/teachingspokenla0000brow/page/2 
Clark, R. C., \& Mayer, R. E. (2016). E-learning and the Science of Instruction: Proven Guidelines for Consumers and Designers of Multimedia Learning. John Wiley \& Sons.

Ekawati, D., \& Yusuf, F. N. (2019, June). Authentic Materials in Fostering EFL Students Listening Comprehension. In Eleventh Conference on Applied Linguistics (CONAPLIN 2018). Atlantis Press.

Erbaggio, P., Gopalakrishnan, S., Hobbs, S., \& Liu, H. (2012). Enhancing Student Engagement Through Online Authentic Materials. IALLT Journal of Language Learning Technologies, 42(2), 27-51.

Gall, M. D., Gall, J. P., \& Borg, W. R. (2003). Education research: An Introduction, 7th Eddition.

Garrison, D. R. (2016). E-learning in the 21st Century: A community of Inquiry Framework for Research and Practice. Taylor \& Francis.

Herod, L. (2002). Adult Learning: From Theory and Practice.

Hutchinson, T., \& Waters, A. (1987). English for Specific Purposes. Cambridge University Press

Peacock, M. (1997). The Effect of Authentic Materials on the Motivation of EFL Learners. ELT journal, 51(2), 144-156.

Richards, J. C., \& Renandya, W. A. (Eds.). (2002). Methodology in Language Teaching: An Anthology of Current Practice. Cambridge University Press.

Seftika, S., Janah, M., \& Syaputri, W. (2017). Improving Students' Understanding of Indonesian Culture Through English Learning Based Local Culture Context. ELT-Lectura, 4(2), 217562.

Tomlinson, B. (2012). Materials development for Language Learning and Teaching. Language teaching, 45(2), 143-179.

Wallace, T., Stariha, W. E., \& Walberg, H. J. (2004). Teaching speaking, Listening and Writing. International Academy of Education. 